Correction

\title{
Correction: Beran et al. Inosine Pranobex Significantly Decreased the Case-Fatality Rate among PCR Positive Elderly with SARS-CoV-2 at Three Nursing Homes in the Czech Republic. Pathogens 2020, 9, 1055
}

\author{
Jirí Beran ${ }^{1, * \mathbb{D}}$, Marian Špajdel ${ }^{2}$, Věra Katzerová ${ }^{3}$, Alena Holoušová ${ }^{4}$, Jan Malyš ${ }^{4}$, Jana Finger Rousková ${ }^{5,6}$ \\ and Jiří Slíva 6 \\ 1 Department for Tropical, Travel Medicine and Immunization, Institute of Postgraduate Health Education, \\ 10005 Prague, Czech Republic \\ 2 Department of Psychology, Faculty of Philosophy and Arts, Trnava University, 91843 Trnava, Slovakia; \\ marian.spajdel@truni.sk \\ 3 Domov Důchodců Litovel, 78401 Litovel, Czech Republic; katzerova@volny.cz \\ 4 Sanatorium Topas, 53401 Holice, Czech Republic; alena.holousova@sanatorium-topas.cz (A.H.); \\ jan.malys@sanatorium-topas.cz (J.M.) \\ 5 Senior dům Beránek Úpice, 54232 Úpice, Czech Republic; rouskova.jana@email.cz \\ 6 Department of Pharmacology, Third Faculty of Medicine, Charles University, 10000 Prague, Czech Republic; \\ slivaj@seznam.cz \\ * Correspondence: jiri.beran@vakcinace.cz; Tel.: +420-603-113-867 or +420-495-541-584
}

check for

updates

Citation: Beran, J.; Špajdel, M.; Katzerová, V.; Holoušová, A.; Malyš, J.; Rousková, J.F.; Slíva, J. Correction: Beran et al. Inosine Pranobex Significantly Decreased the Case-Fatality Rate among PCR Positive Elderly with SARS-CoV-2 at Three Nursing Homes in the Czech Republic. Pathogens 2020, 9, 1055. Pathogens 2021, 10, 1121. https:// doi.org/10.3390/pathogens10091121

Received: 12 June 2021

Accepted: 18 June 2021

Published: 2 September 2021

Publisher's Note: MDPI stays neutra with regard to jurisdictional claims in published maps and institutional affiliations.

Copyright: (c) 2021 by the authors. Licensee MDPI, Basel, Switzerland. This article is an open access article distributed under the terms and conditions of the Creative Commons Attribution (CC BY) license (https:// creativecommons.org/licenses/by/ $4.0 /)$.
There was an error in the original article [1]. The authors wish to remove words "of this prospective trial" from the last paragraph of Section 1 (on Page 4, row 8) and delete "prospective clinical" from Section 4.1 (first sentence of this Section on Page 8). The corrected sentences are as follows:

In last paragraph of Section 1 (on Page 4, row 8): “The aim was to critically assess the possible benefits of IP in the prevention and treatment of COVID-19 in nursing home settings." and in Section 4.1 (first sentence of this Section on Page 8), "This study was performed in three nursing homes in three towns (Litovel, Sanatorium Topas Holice, and Beránek Úpice) in the Czech Republic".

The authors apologize for any inconvenience caused and state that the scientific conclusions are unaffected. The original article has been updated.

\section{Reference}

1. Beran, J.; Špajdel, M.; Katzerová, V.; Holoušová, A.; Malyš, J.; Rousková, J.F.; Slíva, J. Inosine Pranobex Significantly Decreased the Case-Fatality Rate among PCR Positive Elderly with SARS-CoV-2 at Three Nursing Homes in the Czech Republic. Pathogens 2020, 9, 1055. [CrossRef] [PubMed] 